\title{
Fluorescence Assays for Biotransformations
}

Jean-Louis Reymond

\section{1 \\ Introduction}

High-throughput activity screening in microbial collections, expression libraries of enzyme mutants, or metagenomic libraries using enzyme activity assays is one of the key steps in the development of new or improved biocatalysts. Ideally, screening is carried out with the authentic reaction of interest under its operating conditions and reaction progress is monitored using analytical instruments such as high-performance liquid chromatography, gas chromatography, nuclear magnetic resonance, or mass spectrometry, or simply thin-layer chromatography. In most laboratories, however, such analyses are not realizable in high-throughput or in the format imposed by the expression conditions of the library under study. In such cases the enzyme discovery process can be assisted by a fluorescence assay. Fluorescence can be recorded with high sensitivity in a variety of settings, in particular in a high-throughput screening format such as microtiter plates, micro-arrays, or fluorescence-activated cell sorting. Fluorescence is also usually directly visible by the eye under illumination with an ultraviolet (UV) lamp.

Fluorescence monitoring of a biotransformation is possible either by coupling the reaction of interest to a fluorogenic sensor system, for example an enzymecoupled assay linking the reaction to the production or consumption of $\mathrm{NAD}^{+}$or by using a fluorogenic model substrate instead of the authentic substrate. Fluorogenic substrates are particularly useful for high-throughput screening and routine identification of an enzyme during cloning when it has been established that this enzyme catalyzes the desired reaction. In recent years the author and others have reported on a variety of fluorescence sensors and substrates that expand the chemistry of classical assays to a broad diversity of reactions and substrates. The present chapter reviews the development of fluorogenic substrates based on umbelliferone and related fluorescent phenols by the author's research group and related reports by others. A more general presentation of recent advances in high-throughput screening assays for biotransformations has been recently published [1]. 
1.2

\section{Alcohol Dehydrogenases (ADHs) and Aldolases}

Alcohol dehydrogenases and aldolases are some of the most synthetically significant enzymes in biocatalysis because they carry out classical and highly useful reactions with ketones and aldehydes that generate new asymmetric centers. Although only a limited number of these enzymes are currently in use, their potential for complex asymmetric synthesis is very high and efficient fluorogenic substrates are particularly important for facilitating research in this area.

\subsection{1}

\section{Chiral Fluorogenic ADH Substrates}

Alcohol dehydrogenases can be assayed by following the conversion of $\mathrm{NAD}(\mathrm{P})^{+}$ to $\mathrm{NAD}(\mathrm{P}) \mathrm{H}$ at $340 \mathrm{~nm}$, either by $\mathrm{UV}$ or by fluorescence. However, the signal is often obscured by contaminants or other assay components if the assay is done in whole cells or in the presence of other chromophores and the reduced forms of the co-factors are not very stable. Signal stability is also a problem in indirect assays where the reduced co-factors are detected in a colorimetric secondary reaction such as the formazane test [2]. As an alternative to these methods, one can consider using a fluorogenic or chromogenic alcohol substrate as a reporter for the reaction. Umbelliferyl ethers of chiral 1,3-diols such as 1, 2, or 3 that serve as fluorogenic substrates for alcohol dehydrogenases have been developed (Scheme 1.1) [3-5]. The alcohols are obtained by alkylation of an umbelliferyl anion with activated precursors and this allows various substitution patterns and stereochemistries to be installed around the enzyme reactive functional group. The enzyme<smiles>C[C@@H](O)CCOc1ccc2ccc(=O)oc2c1</smiles>

1<smiles>C[C@H](CO)COC(=O)O</smiles>

2<smiles>C[C@H](C=O)COC(=O)O</smiles><smiles>O=C(O)OCC[C@@H](O)CBr</smiles>

3

4<smiles>CCCCCCC(=O)OCC(C)C</smiles><smiles>O=c1ccc2ccc(O)cc2o1</smiles>

Scheme 1.1 Chiral fluorogenic alcohol dehydrogenase substrates and assay conditions. 
to the corresponding carbonyl (e.g. 4) oxidizes the alcohol function and this spontaneously liberates the fluorescent product umbelliferone 5 by $\beta$-elimination. This secondary reaction occurs above $\mathrm{pH} 7$ and can be catalyzed by the addition of bovine serum albumin (BSA). The alkaline $\mathrm{pH}$ is also necessary because the fluorescent umbelliferone anion only exists above $\mathrm{pH}$ 7. The blue fluorescent signal produced around $440 \mathrm{~nm}$ increases over 20 -fold upon conversion of the alcohol substrates to umbelliferone and is visible by the naked eye under illumination with UV light, which is particularly convenient during screening. On the other hand the $\beta$-elimination process has a half-life of 3-15 min depending on the substrate, which limits the reaction kinetics if the alcohol oxidation itself is very fast. Therefore the assay is only suitable for kinetic studies under slow reaction conditions, for example using low enzyme concentrations.

\section{2 .2}

\section{Fluorogenic Aldolase Probes}

The discovery of aldolase catalytic antibodies in the 1990s [6-8] led to an interest in screening biocatalytic aldol reactions of non-natural aldolase-type substrates. The ADH assay above can be modified in the form of aldol substrates such as $\mathbf{6}$ to assay retro-aldolization reactions via a retro-aldol/ $\beta$-elimination sequence. The aldolase substrate $\mathbf{6}$ and analogs are prepared by direct synthesis from aldehyde 4 (Scheme 1.2) [9, 10]. Aldehyde 4 is unstable towards $\beta$-elimination in water, but can be handled in organic solvent. For instance, the reaction of aldehyde with silyl enolethers under catalysis by $\mathrm{SnCl}_{4}$ at low temperature in dichloromethane proceeds in excellent yields without $\beta$-elimination to deliver a stereoisomeric mixture of aldol 6, which can then be separated by high-performance liquid chromatography for individual assays. The retro-aldol reaction can also be assayed with aldol 7, which follows the same mechanism as $\mathbf{6}$, as well as with aldols 8 and $\mathbf{9}$, which directly yield a fluorescent aldehyde product upon retro-aldolization, as shown by List et al. [11]. The advantage of assaying retro-aldol reactions as opposed to the<smiles>CCC(=O)[C@H](C)[C@H](O)CCOc1ccc2ccc(=O)oc2c1</smiles>

6<smiles>COc1ccc2cc(C(O)CC(C)=O)ccc2c1</smiles>

8<smiles>CC(=O)CC(C)(O)CCOc1ccc2nc3ccc(=O)cc-3oc2c1</smiles>

7<smiles>CC(=O)CC(O)/C=C/c1ccc(N(C)C)cc1</smiles>

9

Scheme 1.2 Fluorogenic substrates for aldolase catalytic antibodies and related biocatalysts. 
<smiles>O=C(O)C(=O)OC[C@H]1OC(O)(CO)C(O)[C@H]1O</smiles>

10<smiles>CC(=O)OCCC(O)C(O)C(=O)CO</smiles>

11<smiles>CC(C)OCC[C@H](O)C(O)C(=O)CO</smiles>

12<smiles>CC(=O)OCC(O)C(O)C(=O)CO</smiles>

13

Scheme 1.3 Fluorogenic substrates for transaldolase and transketolase.

forward reaction lies in the possibility of testing individual stereoisomers of the aldol product for reactivity, leading to a prediction of stereoselectivity, as was analyzed using all eight diastereoisomers of aldol 6 [10].

\section{2 .3}

\section{Transaldolases and Transketolases}

Related systems were later developed for transaldolases 10-12 (Scheme 1.3) [12]. The fructo/tagato stereoselectivity of various transaldolases was determined by fluorescence for the stereoisomeric substrate pair 11/12. However, the reactivity of the substrates towards transaldolases is much lower than with the natural substrate due to the replacement of the phosphate group at position 6 of the natural fructose-6-phosphate substrate with the neutral, aromatic coumarin ether, which is not well recognized by the enzyme. Sevestre et al. [13] reported substrate $\mathbf{1 3}$ as a fluorogenic substrate for transketolases, based on a similar fluorescence release mechanism.

It should be mentioned that most natural aldolase enzymes can also be assayed using enzyme-coupled systems relaying the reaction to a redox process with NAD ${ }^{+}$. The formation of NADH by active microbial colonies in expression libraries of mutant enzymes was detected colorimetrically in agar plates using phenazine methosulfate and nitroblue tetrazolium, which forms an insoluble precipitate. The assay was used by Williams et al. [14] and Woodhall et al. [15] for evolving sialic acid aldolases to accept non-natural aldehyde acceptors.

\subsection{4}

\section{Enolase Probe}

Aldolase-type biocatalysts can generally also be expected to catalyze the enolization of the ketone donor. However, directly detecting enolization by fluorescence is not possible. It was recently found that dihydroxyacetone coumarin ether $\mathbf{1 4}$ functions 
<smiles>O=C(CO)COc1ccc2ccc(=O)oc2c1</smiles>

14<smiles>CCCc1coc2ccc([N+](=O)[O-])cc12</smiles>

15<smiles>N#Cc1cc([N+](=O)[O-])ccc1O</smiles>

16

Scheme 1.4 Substrates to assay enolization and deprotonation at carbon.

as a fluorogenic enolization probe in aqueous buffer (Scheme 1.4) [16]. Enol formation is followed by $\beta$-elimination of umbelliferone and the corresponding fluorescence signal. The probe detects the activity of a variety of small molecule enolization catalysts and is generally useful for screening aldolase type biocatalysts [17]. Alkylation of umbelliferone with allyl bromide, dihydroxylation of the allyl ether double bond, silylation of the primary alcohol, oxidation of the secondary alcohol to the ketone, and acidic deprotection provide excellent yields of the probe.

Enolization involves a deprotonation step at carbon, which is a fundamental reaction step of interest in studying the principles of enzyme action. Investigations of biocatalytic carbon deprotonation have focused on the chromogenic ring opening of nitrobenzoxazole $\mathbf{1 5}$ to form the yellow product 2-cyano-4-nitrophenol $\mathbf{1 6}$. The reaction is promoted by weak bases such as carboxylate side chains in a hydrophobic environment, in particular with albumins and catalytic antibodies [18-21]. The unstable aldehyde 4 (Scheme 1.1) and related carbonyls also provide interesting fluorogenic substrates for such reactions and the $\beta$-elimination process is indeed catalyzed by BSA in an enzyme-like manner [3].

\section{3}

\section{Lipases and Esterases}

Lipases and esterases can be assayed using $\mathrm{pH}$ indicators. A particularly elegant implementation of this principle was reported by the group of Kazlauskas for screening enantioselectivities using the Quick E assay [22, 23]. A variety of other high-throughput screening assays have been reported based on the chemoselective detection of the reaction products from untagged esters. These include fluorogenic hydrazone formation with acetaldehyde produced by lipase/esterase-catalyzed transesterification of vinyl esters in organic solvents [24], the detection of acetic acid produced from acetate esters using an enzyme kit [25], or the back titration of periodate with adrenaline after oxidation of the glycerol release from triglyceride hydrolysis [26, 27].

Various chromogenic and fluorogenic esters for lipases and esterase are also available commercially in the form of simple esters of umbelliferone or 
$p$-nitrophenol. Unfortunately such substrates are often relatively unreactive towards the enzyme while displaying a high level of non-specific hydrolysis in the reaction medium. In order to overcome these limitations various assays and substrates that significantly improve the fluorogenic detection of lipases and esterases have now been developed.

\subsection{1}

\section{Assays on Solid Support}

The disadvantage of esters of umbelliferone or nitrophenol esters as lipase substrates lies in their low aqueous solubility and high non-specific reactivity in water. Because lipases are interfacial enzymes, there has been a search for an assay format where these substrates would be presented to the enzyme solution in stable, insoluble form over a high surface material. The best implementation of this principle consists of impregnating silica gel plates (used for analytical thinlayer chromatography) with a solution of the umbelliferone esters in dichloromethane [28]. Evaporation of the solvent leaves the substrate homogeneously adsorbed on the surface. The silica gel plates can then be used for assaying enzymes by simply adding a drop of test solution to the surface. The buffer impregnates the plate and the substrates are dissolved and hydrolyzed if an active enzyme in present. This format is extremely practical since it allows the assay volume to be reduced to only $1 \mu \mathrm{l}$ per assay. Its use has been demonstrated in high-throughput by profiling 35 different enzymes across 20 different ester substrates, realizing over 7000 individual assays in a matter of hours. The cyclohexane carboxylic ester 17, which releases 4-methylumbelliferone 18 as a fluorescent product, appeared as the most uniformly reactive substrate across all lipases and esterases tested (Scheme 1.5). It should be mentioned that silica gel plates can be impregnated with fluorogenic substrates for other enzymes, for example umbelliferyl glycosides for testing glycosidases.

The photograph insert shows a typical plate impregnated with substrate 17 under UV illumination after reaction of $1-\mu$ l reactions containing various lipases (columns 1-10) or controls (BSA) (columns 11 and 12) under various conditions (lanes A-L) (see the original publication for details).

Substrate micro-arrays for testing lipases have also been investigated (Scheme 1.6) [29]. The assay is based on an indirect tagging strategy involving periodate cleavage of a primary 1,2-diol product followed by chemoselective tagging with rhodamine sulfohydrazide. The tag becomes covalently attached to the surface whenever an aldehyde product has been formed and its red fluorescence can be quantified using a standard micro-array scanner. The 1,2-diol esters showed the desired chemical stability on the micro-array and the 1,2-diol could be successfully tagged chemoselectively using the hydrazide reagent without non-specific staining under appropriate washing conditions. However, most lipases proved unreactive in the assay and the most reactive enzymes on the micro-array were not those most active in solution, highlighting strong differences between the two reaction formats. 
1.3 Lipases and Esterases $\mid 7$
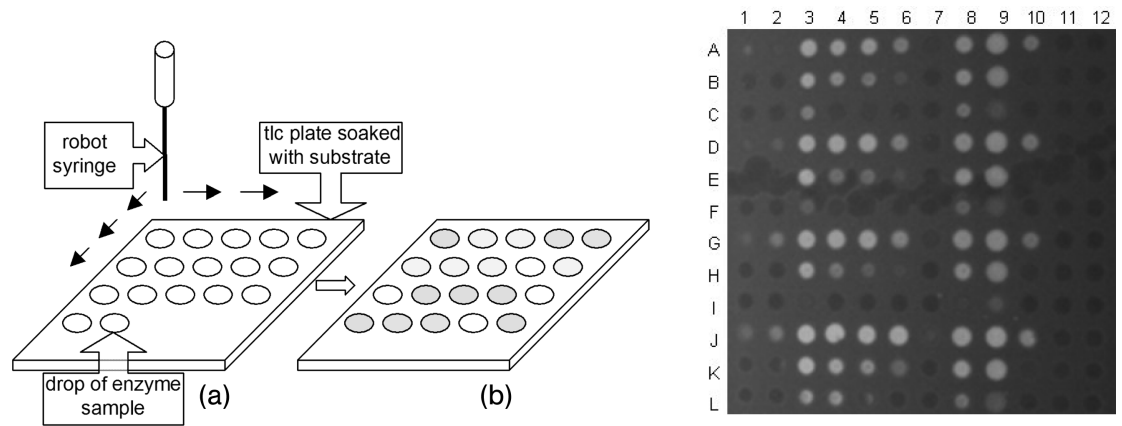<smiles>Cc1cc(=O)oc2cc(OC(=O)C3CCCCC3)ccc12</smiles>

17<smiles>Cc1cc(=O)oc2cc(O)ccc12</smiles>

18

Scheme 1.5 Fluorescence lipase assay on a solid support.
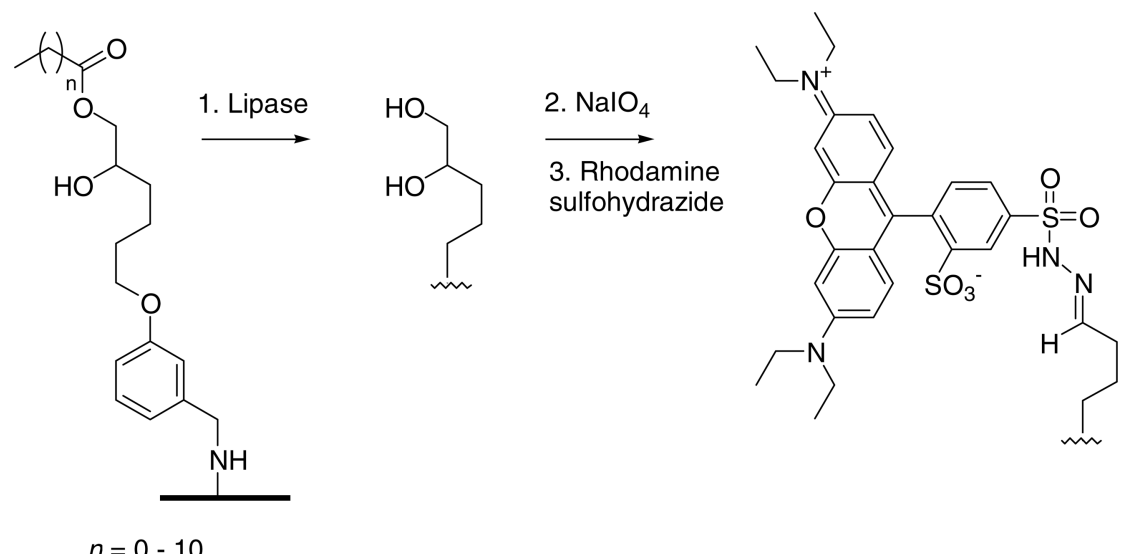

$n=0-10$

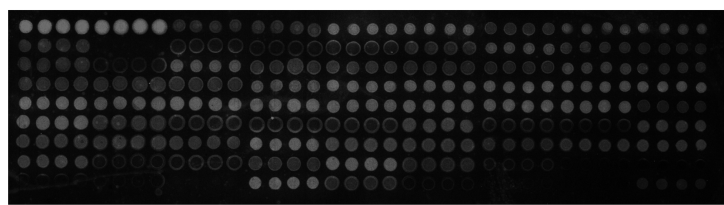

Scheme 1.6 A substrate micro-array for testing lipases. 


\subsection{2}

\section{The Clips-O Substrates with Periodate}

The Clips-O substrates form one of the most reliable classes of fluorogenic and chromogenic substrates for hydrolytic enzymes, in particular for lipases (e.g. 19) [30-32]. These substrates are based on a double indirect release mechanism for the fluorescence signal exploiting sequential cleavage of a primary 1,2-diol product (e.g. 20) with sodium periodate to form an unstable aldehyde or ketone (e.g. 21), which undergoes $\beta$-elimination to release umbelliferone $\mathbf{5}$ or nitrophenol (Scheme 1.7). Sodium periodate oxidizes 1,2-diols and 1,2-aminoalcohols selectively, but does not interact with most of the other functional groups, in particular the substrates of the assay and the enzymes. This indirect release strategy separates the enzyme reactive functional group from the fluorescent label. In addition, the functional group reacting with the enzyme is non-activated and therefore much less prone to uncatalyzed spontaneous hydrolysis in the assay medium. The ClipsO substrate 19 is particularly reactive with lipases because the enzyme reactive ester is part of a 1,2-diol monoester function resembling the natural glyceride ester substrates of these enzymes [33].

Interestingly, it has been found that 19 not only reacts well with lipases, but also shows a high reactivity with esterases, such that the substrate serves as a general<smiles>CCCCCCCCCC(=O)OCC(O)CCOc1ccc2ccc(=O)oc2c1</smiles>

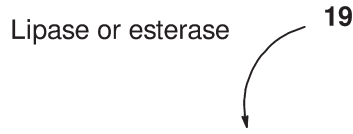<smiles>O=c1ccc2ccc(OCCC(O)CO)cc2o1</smiles>

20

19<smiles>CCCCCC</smiles><smiles>CCCOc1ccc2ccc(=O)oc2c1</smiles>

21<smiles>[X]c1cc(OCCC(O)COC(=O)CCCCCCCCC)ccc1[N+](=O)[O-]</smiles>

$22(\mathrm{X}=\mathrm{H})$

$23\left(\mathrm{X}=\mathrm{NO}_{2}\right)$

Scheme 1.7 Clips-O substrates for lipases and esterases. 
reference fluorogenic substrate for esterases and lipases. An enzyme fingerprinting study involving eight enantiomeric pairs of analogs of 19 with various acyl chain length showed that lipases and esterases can be distinguished by their chain length selectivity [34]. The corresponding nitrophenyl and dinitrophenyl derivatives 22 and 23 display similar reactivities [35]. As for the ADH and aldolase assays discussed above (Scheme 1.1), the secondary decomposition of the 1,2-diol product leading to umbelliferone may be kinetically limiting in the assay, implying that the substrates are not suitable for following the kinetics of very fast enzymes.

\subsection{3}

\section{Esters of Fluorogenic Cyanohydrins and Hydroxyketones}

Using aliphatic alcohols rather than acidic phenols in the ester function of lipase and esterase substrates is the key to obtaining selective probes for these enzymes. In the examples above the problem was solved by using an oxidative decomposition of the primary aliphatic alcohol product. Fluorogenic cyanohydrins and hydroxyketones that spontaneously react to form a fluorescent phenol following the $\beta$-elimination sequence presented above have been investigated as alternative reagent-free versions of fluorogenic aliphatic alcohols (Scheme 1.8) [36]. Reaction of the unstable aldehyde 21 with cyanotrimethyl silane (TMSCN) in dichloromethane and acidic hydrolysis of the trimethylsilyl (TMS) group affords cyanohydrin 25 without $\beta$-elimination. The cyanohydrin 25 can then be esterified with various acyl chlorides to afford the corresponding esters such as 24 . These substrates undergo a fluorogenic reaction with lipases and esterases. The enzyme-catalyzed<smiles>CCCC(=O)OC(C#N)CCOc1ccc2ccc(=O)oc2c1</smiles>

24

$$
\text { = Coum }
$$<smiles>O=c1ccc2ccc(O)cc2o1</smiles>

5

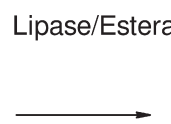<smiles>N#CC(O)CCOC(=O)O</smiles>

25

$\uparrow-\mathrm{HCN}$<smiles>O=CCCOC(=O)O</smiles>

21<smiles>CCCCCCCCCC(=O)OCC(=O)COc1ccc2ccc(=O)oc2c1</smiles>

26

Scheme 1.8 Fluorogenic cyanohydrins and hydroxyketone esters. 
ester hydrolysis liberates the cyanohydrin 25 , which then undergoes a rapid and spontaneous decomposition in aqueous buffer to form umbelliferone as a fluorescent product. Interestingly, the equilibration of the cyanohydrin 25 to the aldehyde 21 is faster than the $\beta$-elimination.

The fluorogenic hydroxyketone 14 discussed above (Scheme 1.4) can also be used to form esters such as $\mathbf{2 6}$ which can be used as fluorogenic substrates for lipases [37]. In this case, however, the esters are quite unstable despite being aliphatic alcohol esters. The relatively rapid spontaneous hydrolysis in this case is probably due to an assisted mechanism involving acyl transfer in the hydrated form of the ketone.

\subsection{4}

\section{Fluorogenic Acyloxymethyl Ethers}

Alkylation of umbelliferone with chloromethyl esters of various aliphatic acids affords the corresponding acyloxymethyl ethers (e.g. 27) in good yields [38]. These substrates undergo lipase/esterase-catalyzed hydrolysis in buffer to form umbelliferone (Scheme 1.9) [39]. The mechanism probably involves an unstable hemiacetal intermediate, which spontaneously reacts to formaldehyde and umbelliferone 5. The substrates can also be prepared in a two-step sequence involving alkylation of umbelliferone with 2-chloroketones followed by Baeyer-Villiger oxidation. The sequence is particularly interesting for obtaining the fluorogenic lactones 28 and 29, which only react with esterases [40].

The alkylation chemistry described above can also be applied with fluorescein to yield the corresponding fluorescein mono-ethers such as $\mathbf{3 0}$ as green fluorescent probes for lipases [41]. These substrates are water soluble due to the anionic carboxylate on the fluorescein group and can be used in pure aqueous buffer without any co-solvent. This latter class of substrates reacts extremely fast and specifically with the enzymes, with assay times under $1 \mathrm{~min}$. An activity fingerprinting study<smiles>CC(C)C(=O)OCOc1ccc2ccc(=O)oc2c1</smiles>

27<smiles>O=C(O)OC1CCCC(=O)O1</smiles>

28<smiles>CC(=O)OC1CCCCC(=O)O1</smiles>

29<smiles>CCCCCCCC(=O)OCOc1ccc2c(-c3ccccc3C(=O)[O-])c3ccc(=O)cc-3oc2c1</smiles>

30

Scheme 1.9 Fluorogenic acyloxymethyl ethers for lipases and esterases. 
using various fluorescein mono-ether substrates and enzymes either in pure buffer or in buffer containing $20 \% \mathrm{v} / \mathrm{v}$ dimethylsulfoxide co-solvent showed that enzymes classified as esterases react faster in pure aqueous buffer, while those classified as lipases show a stronger reactivity in the presence of the co-solvent, which might be related to the fact that lipases are activated at interfaces.

\subsection{5}

\section{FRET-Lipase Probes}

FRET (fluorescence or Förster resonance energy transfer) is one of the most general principles for designing fluorogenic substrates for bond-cleaving reactions and is well known for protease and lipase substrates. Despite the strong influence of the double labels on reactivity, the use of FRET substrates for lipases has been investigated. A survey of various variations around the 1,2-diol monoester function led to the discovery that most lipases react strongly with the pyrene carboxylic ester 31, which is non-fluorescent due to intramolecular fluorescence quenching by the dinitrophenylamino group, to liberate the fluorescent pyrene butyrate product 32 [42]. The assay is carried out at a low substrate concentration due to the limited solubility and very low $K_{\mathrm{M}}$ values for this substrate. Most interestingly, the substrate is extremely resistant towards non-specific hydrolysis, in particular at alkaline $\mathrm{pH}$. This allows one to screen enzymes under strongly basic conditions, as illustrated for the Roche lipase L8 (Scheme 1.10). A survey of various lipases and esterases at $\mathrm{pH} 11$ showed that most enzymes in fact lose their activity under these conditions.

\section{4}

\section{Other Hydrolases}

Most of the reactivity principles used for fluorogenic lipase substrates are also applicable for other types of hydrolases. Such developments in the case of the epoxide hydrolases, amidases, esterases, and phosphatases have been investigated. Glycosidases were not investigated because the well-known aryl glycosides function perfectly well for their corresponding enzymes, with negligible non-specific reactivity in the absence of enzyme. On the other hand, there is still a need for developing fluorogenic substrates for nitrilases, a further important class of enzymes for biocatalysis.

\subsection{1}

\section{Epoxide Hydrolases}

The 1,2-diol product 20 in the Clips-O lipase substrate 19 (Scheme 1.7) can also form upon hydrolysis of the parent epoxide 33, leading to a convenient periodate coupled assay for epoxide hydrolases with a variety of epoxides (Scheme 1.11) [5, 32, 43]. These substrates are readily prepared in racemic form from umbelliferone by alkylation 
<smiles>CN(CCCOCC(O)COC(=O)CCCc1ccc2ccc3cccc4ccc1c2c34)c1ccc([N+](=O)[O-])cc1[N+](=O)[O-]</smiles>

31<smiles>O=C([O-])CCCc1ccc2ccc3cccc4ccc1c2c34</smiles>

$32\left(\lambda_{\mathrm{em}}=376 \mathrm{~nm}\right)$

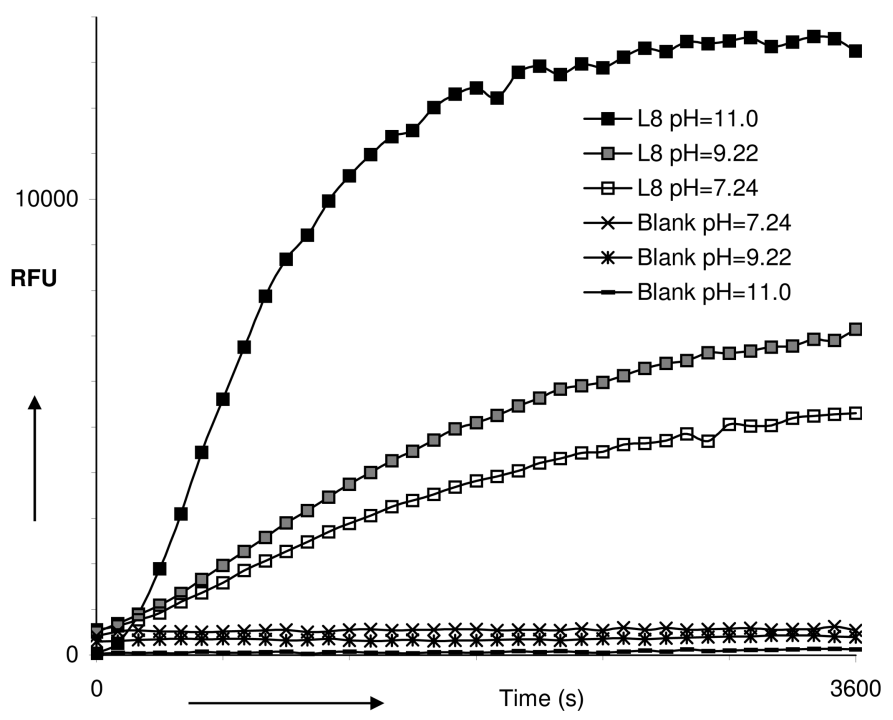

Scheme 1.10 FRET lipase substrate for alkaline assay of lipases.

with an allyl halide and epoxidation of the allyl ether with a peracid. The optically pure fluorogenic epoxides are obtained by asymmetric Sharpless dihydroxylation of the allyl ether, followed by regioselective ring closure. Such enantiomerically pure epoxides may be used for screening enantioselective epoxide hydrolases, although the problem of enantioselectivity is more complex. Indeed epoxide hydrolases enzymes may catalyze epoxide opening at both sides of the epoxide, leading to enantiomeric products [44]. Alternatively, the enzyme reaction may also lead to an enantioconvergent hydrolysis where a racemic epoxide is converted to a single enantiomer of the 1,2-diol [45].

The Clips-O epoxide 33-41 and related substrates are currently the only available selective fluorogenic substrates for EH. On the other hand various indirect assays have been reported to detect either the unreacted epoxide [46] or the carbonyl product resulting from periodate cleavage of the 1,2-diol product [26, 47, 48]. These assays are suitable for fluorescence or colorimetric assays for the hydrolysis of any epoxide of interest. 
<smiles>O=c1ccc2ccc(OCCC3CO3)cc2o1</smiles>

= Coum<smiles>CC1(CCOC(=O)O)CO1</smiles>

(S ) -34<smiles>CC1(C)OC1CCOC(=O)O</smiles>

(S) -35<smiles>CC[C@@H]1O[C@H]1CCOC(=O)O</smiles>

(S,S)-36<smiles>CCC1OC1CCOC(=O)OC</smiles>

$\left(R^{*}, S^{*}\right)-37$<smiles>O=C(O)OC1C[C@@H]2O[C@H]2C1</smiles>

38<smiles>O=COC1C[C@@H]2O[C@H]2C1</smiles>

39<smiles>COc1ccc2cc(C3CO3)ccc2c1</smiles>

(S) -41

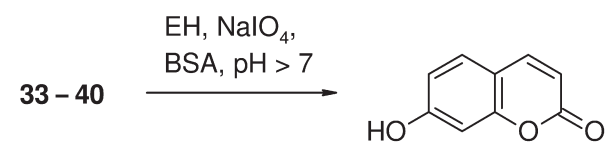

5

Scheme 1.11 Clips-O fluorogenic substrates for epoxide hydrolases.

\section{4 .2}

\section{Amidases and Proteases}

1,2-Aminoalcohols are oxidized by sodium periodate to form the corresponding carbonyl products. The reaction is much faster than for 1,2-diols in a surprisingly $\mathrm{pH}$-independent manner. The reaction can be used for designing non-volatile precursors of fragrant ketones and aldehydes by cyanide addition to form the cyanohydrins and reduction to the corresponding amino alcohol [49]. The oxidative cleavage of 1,2-aminoalcohol for designing selective substrates for amidases such as the phenacetylamide $\mathbf{4 2}$ suitable for screening penicillin $\mathrm{G}$ amidase has been exploited (Scheme 1.12) [32, 43]. A related fluorogenic substrate for ceramidase was also recently reported by others [50]. The phenacetyl derivative 43 also serves a fluorogenic substrate for amidases [37]. This substrate is however completely unstable towards alkaline conditions, probably due to hydrolysis by an assisted mechanism with an intramolecular acyl shift to the hydrated diol as discussed above for the corresponding lipase substrate. A chromogenic threonine derivative to form a selective HIV-protease substrate $\mathbf{4 4}$ has also been prepared [51].

A particularly elegant solution for the assay of proteases and acylases is offered by the fluorogenic detection of free amino acids by decomplexation of copper from calcein, which removes its quenching effect. This principle has been used for assays of acylases, amidases, and proteases (Scheme 1.13) [52, 53]. For the case of proteases combinatorial assays are particularly in demand for testing multiple peptides in parallel and determining the cleavage specificity [54]. New solutions 
<smiles>O=C(Cc1ccccc1)NCC(O)CCOc1ccc2ccc(=O)oc2c1</smiles>

42<smiles>O=C(CNC(=O)Cc1ccccc1)COc1ccc2ccc(=O)oc2c1</smiles>

43

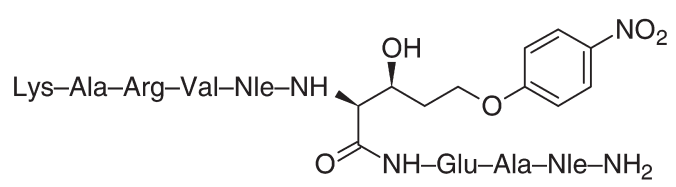

44

Scheme 1.12 Clips-O acylase and amidase substrates.

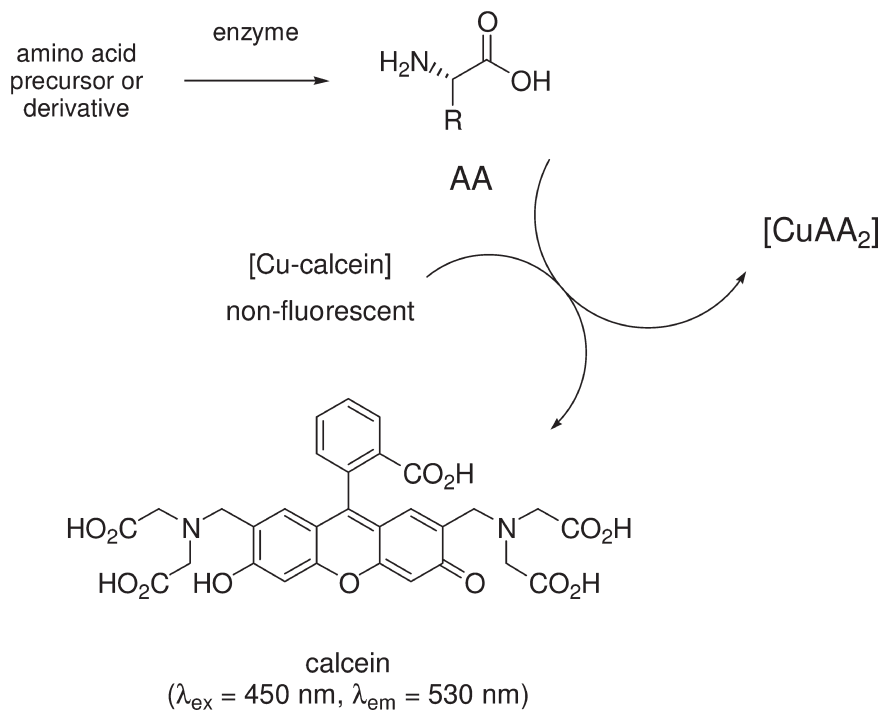

Scheme 1.13 Copper calcein as a fluorogenic sensor for amino acids.

to this problem using cocktails of fluorescence-labeled peptides [55] or combinatorial peptide libraries were recently reported $[56,57]$.

\subsection{3}

\section{Phosphatases}

Although phosphatases are only of moderate interest in organic synthesis, phosphatase enzymes and particularly phytases that hydrolyze phytic acids bearing multiple phosphate groups are of biotechnological interest. The standard substrates for phosphatases are nitrophenyl phosphates and related monophosphates of aromatic phenols. Di- and triphosphates $\mathbf{4 5}$ and $\mathbf{4 6}$ related to the Clips-O principle discussed above have been investigated (Scheme 1.14) [58]. The substrates 
<smiles>O=c1ccc2ccc(OCCC(COP(=O)(O)O)OP(=O)(O)O)cc2o1</smiles>

45<smiles>O=c1ccc2ccc(OCCC(COP(=O)(O)O)(COP(=O)(O)O)OP(=O)(O)O)cc2o1</smiles>

46

Scheme 1.14 Clips-O substrates for phosphatases.

are obtained from the diols by phosphorylation with dibenzyl phosphoramidite, followed by oxidation to the phosphate and debenzylation by hydrogenation. These phosphates display the expected reactivity towards phosphatases, however without selectivity for phytases against alkaline phosphatases, which can be differentiated rather on the basis of their $\mathrm{pH}$ rate profile.

\section{5}

\section{Baeyer-Villigerases}

Baeyer-Villiger monoxygenases (BVMOs) have been recently recognized as preparatively useful enzymes, in particular in relation to their enantioselectivity with prochiral ketones. It has recently been shown that 2-aryloxyketones $\mathbf{4 7 - 5 0}$ act as fluorogenic substrates for these enzymes (Scheme 1.15) [40]. The natural selectivity of oxidative cleavage leads to insertion of the oxygen atom on the side of the aryl ether to form an unstable lactone or acetal ester, which is rapidly hydrolyzed to form umbelliferone. The assay is useful for the detection of BVMOs in whole cells. However, in some cases oxidative activity at the ether methylene group not involving a BVMO reaction was detected as a side reaction with these substrates. The substrates are particularly attractive because they can be prepared in a single step in high yield from commercially available starting materials. They represent to date the only available fluorogenic assay for these enzymes.

\section{6}

\section{Conclusion}

Fluorescence assays for biotransformations are an indispensable tool for enzyme engineering and the daily practice of enzyme studies. Fluorogenic substrates are particularly useful as general probes for enzyme classes that can be used in routine screening and activity checking. However, they cannot replace the authentic substrate in cases where an optimization towards a particular biotransformation is desired. In such cases an indirect fluorogenic assay or an instrumental assay may be required in order to follow the reaction. A variety of fluorescence assays for enzymes still remain to be discovered and the development of new enzyme assays 


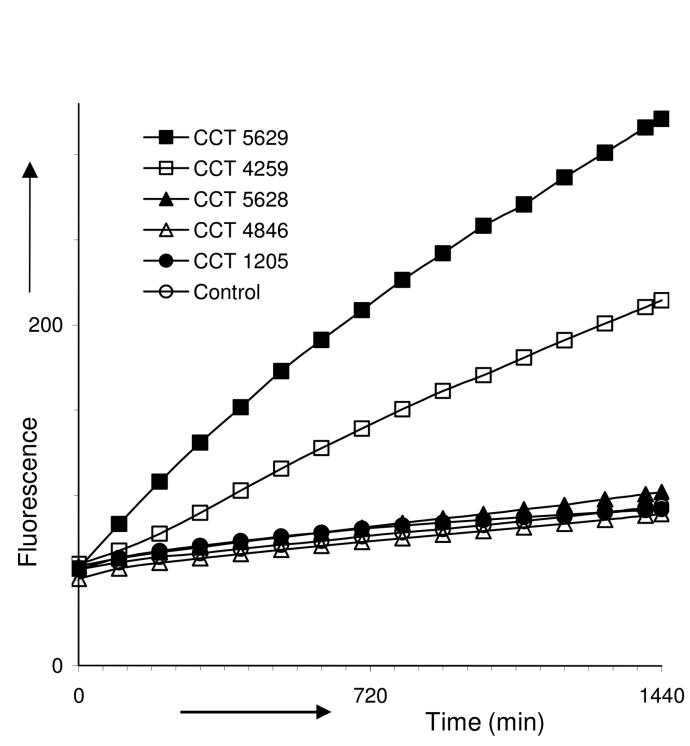

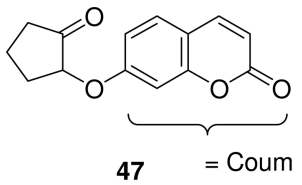

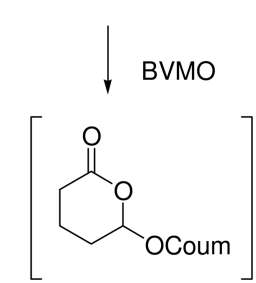

28

Fast hydrolysis in whole cells<smiles>O=c1ccc2ccc(O)cc2o1</smiles>

48<smiles>O=C(O)OC1CCCCC1=O</smiles><smiles>CC(=O)OC(C)C(=O)O</smiles>

49<smiles>CC(=O)COC(=O)O</smiles>

50

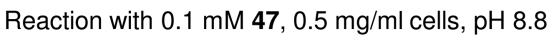

Scheme 1.15 Fluorogenic assay for BVMOs in whole cells.

continues to provide fertile ground for innovative developments. One area of recent progress concerns the use of multiple substrates in parallel assays or as mixtures to record activity profiles, also called fingerprints, which enable the characterization of enzyme activities in great detail [59, 60].

\section{Acknowledgment}

This work was financially supported by the University of Berne, Swiss National Science Foundation, Swiss Federal Office of Education, COST Program Action D25 on Biocatalysis, and Protéus SA, Nîmes, France.

\section{References}

1 Reymond, J.L. (2005) Enzyme Assays: High-throughput Screening, Genetic Selection and Fingerprinting, Wiley-VCH Verlag GmbH, Weiheim.

2 Ravot, G., Wahler, D., Favre-Bulle, O., Cilia, V. and Lefevre, F. (2003) High throughput discovery of alcohol dehydrogenases for industrial biocatalysis. Advanced Synthesis \& Catalysis, 345, 691-694.

3 Klein, G. and Reymond, J.L. (1998) An enantioselective fluorimetric assay for alcohol dehydrogenases using albumincatalyzed beta-elimination of 
umbelliferone. Bioorganic \& Medicinal Chemistry Letters, 8, 1113-1116.

4 Klein, G. and Reymond, J.L. (1999) Enantioselective fluorogenic assay of acetate hydrolysis for detecting lipase catalytic antibodies. Helvetica Chimica Acta, 82, 400-407.

5 Badalassi, F., Klein, G., Crotti, P. and Reymond, J.L. (2004) Fluorescence assay and screening of epoxide opening by nucleophiles. European Journal of Organic Chemistry, 2557-2566.

6 Reymond, J.L. and Chen, Y.W. (1995) Catalytic, enantioselective aldol reaction using antibodies against a quaternary ammonium ion with a primary amine cofactor. Tetrahedron Letters, 36, 2575-2578.

7 Reymond, J.L. and Chen, Y.W. (1995) Catalytic, enantioselective aldol reaction with an artificial aldolase assembled from a primary amine and an antibody. Journal of Organic Chemistry, 60, 6970-6979.

8 Wagner, J., Lerner, R.A. and Barbas III, C.F. (1995) Efficient aldolase catalytic antibodies that use the enamine mechanism of natural enzymes. Science, 270, 1797-1800.

9 Jourdain, N., Carlon, R.P. and Reymond, J.L. (1998) A stereoselective fluorogenic assay for aldolases: detection of an antiselective aldolase catalytic antibody. Tetrahedron Letters, 39, 9415-9418.

10 Perez Carlon, R., Jourdain, N. and Reymond, J.L. (2000) Fluorogenic polypropionate fragments for detecting stereoselective aldolases. Chemistry, 6, 4154-4162.

11 List, B., Barbas, C.F. and Lerner, R.A. (1998) Aldol sensors for the rapid generation of tunable fluorescence by antibody catalysis. Proceedings of the National Academy of Sciences of the United States of America, 95, 15351-15355.

12 Gonzalez-Garcia, E., Helaine, V., Klein, G., Schuermann, M., Sprenger, G.A., Fessner, W.D. and Reymond, J.L. (2003) Fluorogenic stereochemical probes for transaldolases. Chemistry $-A$ European Journal, 9, 893-899.

13 Sevestre, A., Helaine, V., Guyot, G., Martin, C. and Hecquet, L. (2003) A fluorogenic assay for transketolase from

\section{\begin{tabular}{l|l} 
References & 17
\end{tabular}}

Saccharomyces cerevisiae. Tetrahedron

Letters, 44, 827-830.

14 Williams, G.J., Domann, S., Nelson, A. and Berry, A. (2003) Modifying the stereochemistry of an enzyme-catalyzed reaction by directed evolution. Proceedings of the National Academy of Sciences of the United States of America, 100, 3143-3148.

15 Woodhall, T., Williams, G., Berry, A. and Nelson, A. (2005) Creation of a tailored aldolase for the parallel synthesis of sialic acid mimetics. Angewandte ChemieInternational Edition in English, 44, 2109-2112.

16 Kofoed, J., Darbre, T. and Reymond, J.L. (2006) Dual mechanism of zinc-proline catalyzed aldol reactions in water. Chemical Communications (Cambridge, England), 1482-1484.

17 Kofoed, J., Darbre, T. and Reymond, J.L. (2006) Artificial aldolases from peptide dendrimer combinatorial libraries. Organic Q Biomolecular Chemistry, 4, 3268-3281.

18 Kikuchi, K., Hannak, R.B., Guo, M.J., Kirby, A.J. and Hilvert, D. (2006) Toward bi-functional antibody catalysis. Bioorganic Q Medicinal Chemistry, 14, 6189-6196.

19 Debler, E.W., Ito, S., Seebeck, F.P., Heine, A., Hilvert, D. and Wilson, I.A. (2005) Structural origins of efficient proton abstraction from carbon by a catalytic antibody. Proceedings of the National Academy of Sciences of the United States of America, 102, 4984-4989.

20 Manetsch, R., Zheng, L., Reymond, M.T., Woggon, W.D. and Reymond, J.L. (2004) A catalytic antibody against a tocopherol cyclase inhibitor. Chemistry, 10, 2487-2506.

21 Zheng, L., Manetsch, R., Woggon, W.D., Baumann, U. and Reymond, J.L. (2005) Mechanistic study of proton transfer and hysteresis in catalytic antibody 16E7 by site-directed mutagenesis and homology modeling. Bioorganic Q Medicinal Chemistry, 13, 1021-1029.

22 Janes, L.E. and Kazlauskas, R.J. (1997) Quick E. A fast spectrophotometric method to measure the enantioselectivity of hydrolases. Journal of Organic Chemistry, 62, 4560-4561.

23 Janes, L.E., Lowendahl, A.C. and Kazlauskas, R.J. (1998) Quantitative screening of hydrolase libraries using $\mathrm{pH}$ 
indicators: identifying active and enantioselective hydrolases. Chemistry-A European Journal, 4, 2324-2331.

24 Konarzycka-Bessler, M. and Bornscheuer, U.T. (2003) A high-throughput-screening method for determining the synthetic activity of hydrolases. Angewandte Chemie-International Edition in English 42, 1418-1420.

25 Baumann, M., Sturmer, R. and Bornscheuer, U.T. (2001) A highthroughput-screening method for the identification of active and enantioselective hydrolases. Angewandte Chemie-International Edition, 40, 4201-4204.

26 Wahler, D. and Reymond, J.L. (2002) The adrenaline test for enzymes. Angewandte Chemie-International Edition in English, 41, 1229-1232.

27 Wahler, D., Boujard, O., Lefevre, F. and Reymond, J.L. (2004) Adrenaline profiling of lipases and esterases with 1,2-diol and carbohydrate acetates. Tetrahedron, 60, 703-710.

28 Babiak, P. and Reymond, J.L. (2005) A high-throughput, low-volume enzyme assay on solid support. Analytical Chemistry, 77, 373-377.

29 Grognux, J. and Reymond, J.L. (2006) A red-fluorescent substrate microarray for lipase fingerprinting. Molecular Biosystems, 2, 492-498.

30 Badalassi, F., Wahler, D., Klein, G., Crotti, P. and Reymond, J.L. (2000) A versatile periodate-coupled fluorogenic assay for hydrolytic enzymes. Angewandte Chemie-International Edition in English, 39, 4067-4070.

31 Wahler, D., Badalassi, F., Crotti, P. and Reymond, J.L. (2001) Enzyme fingerprints by fluorogenic and chromogenic substrate arrays.

Angewandte Chemie-International Edition in English, 40, 4457-4460.

32 Wahler, D., Badalassi, F., Crotti, P. and Reymond, J.L. (2002) Enzyme fingerprints of activity, and stereo- and enantioselectivity from fluorogenic and chromogenic substrate arrays. Chemistry, 8, 3211-3228.

33 Nyfeler, E., Grognux, J., Wahler, D. and Reymond, J.L. (2003) A sensitive and selective high-throughput screening fluorescence assay for lipases and esterases. Helvetica Chimica Acta, 86, 2919-2927.

34 Grognux, J. and Reymond, J.L. (2004) Classifying enzymes from selectivity fingerprints. Chembiochem, 5, 826-831.

35 Grognux, J., Wahler, D., Nyfeler, E. and Reymond, J.L. (2004) Universal chromogenic substrates for lipases and esterases, Tetrahedron, Asymmetry, 15 , 2981-2989.

36 Leroy, E., Bensel, N. and Reymond, J.L. (2003) Fluorogenic cyanohydrin esters as chiral probes for esterase and lipase activity. Advanced Synthesis \& Catalysis, 345, 859-865.

37 Sicart, R., Collin, M.P. and Reymond, J.L. (2007) Fluorogenic substrates for lipases, esterases, and acylases using a TIMmechanism for signal release. Biotechnol Journal, 2, 221-231.

38 Bensel, N., Reymond, M.T. and Reymond, J.L. (2001) Pivalase catalytic antibodies: towards abzymatic activation of prodrugs. Chemistry, 7, 4604-4612.

39 Leroy, E., Bensel, N. and Reymond, J.L. (2003) A low background high-throughput screening (HTS) fluorescence assay for lipases and esterases using acyloxymethylethers of umbelliferone. Bioorganic a Medicinal Chemistry Letters, 13, 2105-2108.

40 Sicard, R., Chen, L.S., Marsaioli, A.J. and Reymond, J.L. (2005) A fluorescence-based assay for Baeyer-Villiger monooxygenases, hydroxylases and lactonases. Advanced Synthesis a Catalysis, 347, 1041-1050.

41 Yang, Y.Z., Babiak, P. and Reymond, J.L. (2006) New monofunctionalized fluorescein derivatives for the efficient high-throughput screening of lipases and esterases in aqueous media. Helvetica Chimica Acta, 89, 404-415.

42 Yang, Y.Z., Babiak, P. and Reymond, J.L. (2006) Low background FRET-substrates for lipases and esterases suitable for highthroughput screening under basic ( $\mathrm{pH}$ 11) conditions. Organic a Biomolecular Chemistry, 4, 1746-1754.

43 Badalassi, F., Wahler, D., Klein, G., Crotti, P. and Reymond, J.L. (2000) A versatile periodate-coupled fluorogenic assay for 
hydrolytic enzymes. Angewandte Chemie-International Edition, 39, 4067-4070.

44 Archelas, A. and Furstoss, R. (2001)

Synthetic applications of epoxide hydrolases. Current Opinion in Chemical Biology, 5, 112-119.

45 Monterde, M.I., Lombard, M., Archelas, A., Cronin, A., Arand, M. and Furstoss, R. (2004) Enzymatic transformations. Part 58: enantioconvergent biohydrolysis of styrene oxide derivatives catalysed by the Solanum tuberosum epoxide hydrolase, Tetrahedron, Asymmetry, 15, 2801-2805.

46 Zocher, F., Enzelberger, M.M., Bornscheuer, U.T., Hauer, B. and Schmid, R.D. (1999) A colorimetric assay suitable for screening epoxide hydrolase activity. Analytica Chimica Acta, 391, 345-351.

47 Doderer, K., Lutz-Wahl, S., Hauer, B. and Schmid, R.D. (2003) Spectrophotometric assay for epoxide hydrolase activity toward any epoxide. Analytical Biochemistry, 321, 131-134.

48 Mateo, C., Archelas, A. and Furstoss, R. (2003) A spectrophotometric assay for measuring and detecting an epoxide hydrolase activity. Analytical Biochemistry, 314, 135-141.

49 Yang, Y.Z., Wahler, D. and Reymond, J.L. (2003) Beta-amino alcohol properfumes. Helvetica Chimica Acta, 86, 2928-2936.

50 Bedia, C., Casas, J., Garcia, V., Levade, T. and Fabrias, G. (2007) Synthesis of a novel ceramide analogue and its use in a high-throughput fluorogenic assay for ceramidases. Chembiochem, 8 , 642-648.

51 Badalassi, F., Nguyen, H.K., Crotti, P. and Reymond, J.L. (2002) A selective

\section{References 19}

HIV-protease assay based on a chromogenic amino acid. Helvetica Chimica Acta, 85, 3090-3098.

52 Klein, G. and Reymond, J.L. (2001) An enzyme assay using pM. Angewandte Chemie-International Edition, 40, 1771-1773.

53 Dean, K.E.S., Klein, G., Renaudet, O. and Reymond, J.L. (2003) A green fluorescent chemosensor for amino acids provides a versatile high-throughput screening (HTS) assay for proteases. Bioorganic \& Medicinal Chemistry Letters, 13, 1653-1656.

54 Diamond, S.L. (2007) Methods for mapping protease specificity. Current Opinion in Chemical Biology, 11, 46-51.

55 Yongzheng, Y. and Reymond, J.L. (2005) Protease profiling using a fluorescent domino peptide cocktail. Molecular Biosystems, 1, 57-63.

56 Kofoed, J. and Reymond, J.L. (2007) A general method for designing combinatorial peptide libraries decodable by amino acid analysis. Journal of Combinatorial Chemistry, 9, 1046-1052.

57 Kofoed, J. and Reymond, J.L. (2007) Identification of protease substrates by combinatorial profiling on TentaGel beads. Chemical Communications (Cambridge, England), 4453-4455.

58 Gonzalez-Garcia, E.M., Grognux, J., Wahler, D. and Reymond, J.L. (2003) Synthesis and evaluation of chromogenic and fluorogenic analogs of glycerol for enzyme assays. Helvetica Chimica Acta, 86, 2458-2470.

59 Reymond, J.L. and Wahler, D. (2002) Substrate arrays as enzyme fingerprinting tools. Chembiochem, 3, 701-708.

60 Goddard, J.P. and Reymond, J.L. (2004) Enzyme activity fingerprinting with substrate cocktails. Journal of the American Chemical Society, 126, 11116-11117. 
